

\section{Sektorprogram Kultur}

Danmarks formandskab for Nordisk Ministerråd 2015

ISBN 978-92-893-3911-7 (PRINT)

ISBN 978-92-893-3912-4 (PDF)

http://dx.doi.org/10.6027/ANP2015-702

ANP 2015:702

(C) Nordisk Ministerråd 2015

Lillegrund Vindmøllepark

Layout: Erling Lynder

Omslagsfoto: Havvindmøller i Øresund,

Adrian Joachim og Signelements

Foto: s. 5 Nicolas Tobias Følsgaard; s.6-7 Johannes Jansson;

s. 8 Yadid Levy; s. 12-13 Mette Mjöberg Tegnander;

s. 15 Yadid Levy; s. 16 Ane Cecilie Blichfeldt; s. 18 Signelements

Tryk: Rosendahls-Schultz Grafisk

Oplag: 500

Printed in Denmark

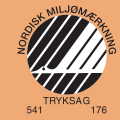

www.norden.org/da/publikationer

\section{Det nordiske samarbejde}

Det nordiske samarbejde er en af verdens mest omfattende regionale samarbejdsformer. Samarbejdet omfatter Danmark, Finland, Island, Norge og Sverige samt Færøerne, Grønland og Åland.

Det nordiske samarbejde er både politisk, økonomisk og kulturelt forankret, og er en vigtig medspiller i det europæiske og internationale samarbejde. Det nordiske fællesskab arbejder for et stærkt Norden i et stærkt Europa.

Det nordiske samarbejde ønsker at styrke nordiske og regionale interesser og værdier i en global omverden. Fælles værdier landene imellem er med til at styrke Nordens position som en af verdens mest innovative og konkurrencedygtige regioner.

\section{Nordisk Ministerråd}

Ved Stranden 18

1061 København K

Telefon (+45) 33960200

www.norden.org 


\section{norden}

SEKTORPROGRAM

\section{Kultur}

Dansk formandskab for Nordisk Ministerråd 2015

1 Forord

2 Indledning

3 Det kreative Norden

4 Det unge Norden

5 Det bæredygtige Norden

6 Det digitale Norden 


\section{Forord}

Kunsten og kulturen har en enestående evne at skabe dialog på tværs af landegrænser. Det oplever jeg gang på gang, når jeg besøger andre lande i forbindelse med internationale kulturbegivenheder.

Jeg ser frem til endnu en gang at opleve denne energi, når Danmark i 2015 har formandskabet for Nordisk Ministerråd. Et formandskab, hvor vi sætter fokus på kultursamarbejdet blandt vores nære venner i de nordiske lande. Men i høj grad også et formandskab, hvor ambitionen er at rette dialogen ud $i$ verden.

Vi vil under formandskabet arbejde med temaerne "Det kreative Norden", "Det unge Norden", "Det bæredygtige Norden" og "Det digitale Norden". Alle temaer, som på hver sin måde rummer stor aktualitet netop nu - såvel i Danmark som i resten Norden og resten af verden.

For hvordan udnytter vi den opmærksomhed, som Det kreative Norden nyder i øjeblikket, hvor alt kunst og kultur med overskriften "Nordic" er synonym med kvalitet og nytænkning? Tænk bare på litteraturen, billedkunsten, musikken, designen, gastronomien osv. Og hvordan sikrer vi, at børn og unge i Norden møder kunsten og kulturen så tidligt så muligt i deres opvækst - også dem der vokser op uden klaver og museumsabonnement i hjemmet? Hvordan arbejder vi med kunsten og kulturen som drivkraft for en bæredygtig udvikling af samfundet? Og endelig er der den digitale udfordring: Hvordan kommer vi på forkant med udviklingen i mediebilledet og i den forbindelse udvikler vores nordiske, og på verdensplan unikke, begreber om public service?

Disse spørgsmål skal ikke bare drøftes blandt de nordiske politikere. De skal drøftes med kulturinstitutioner, kunstnere og borgere - børn og unge som ældre. Derfor rummer dette sektorprogram for det danske formandskab på kulturområdet også en række arrangementer, som går på tværs af politiske niveauer, og som tager udgangspunkt $\mathrm{i}$ inddragelsen af de nordiske kulturinstitutioner og borgere. Alle er inspiration til den politiske diskussion af, hvornår og hvordan det giver bedst mening for os at stå sammen om kultursamarbejdet, og hvordan vi mest hensigtsmæssigt udveksler kultur med resten af verden. 
De nævnte temaer har det tilfælles, at de tager udgangspunkt i mennesker - som individer og samfundsborgere med grundlæggende demokratiske rettigheder. I temaerne afspejles centrale værdier, som vi deler i Norden.

Jeg byder alle velkommen til kultursamarbejdet under Danmarks formandskab for Nordisk Ministerråd i 2015.

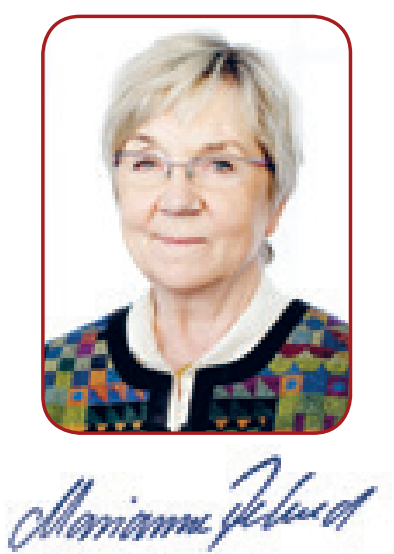

Marianne Jelved

Kulturminister 


\section{Indledning}

Det nordiske kultursamarbejde spiller en grundlæggende rolle i samarbejdet i Nordisk Ministerråd. Kulturen er det, der binder os sammen og gør os til en region, hvor vi på tværs af landene kender hinanden og forstår hinanden og frem for alt har en hel del tilfælles. Det nordiske samarbejde er dybt forankret i vores kultur, sprog, historie, værdier og måder at gøre tingene på.

Danmarks formandskab for Nordisk Ministerråd i 2015 prioriterer de tværgående temaer vækst, velfærd og værdier og Det Blå Arktis. Det vil også være en tværgående prioritet at fokusere samarbejdet på områder, hvor det giver klar nordisk merværdi.

Skønt de nordiske lande, Grønland, Færøerne og Åland på ingen måde er identiske, er befolkningen i Norden præget af en række gennemgående kerneværdier om åbenhed, demokrati, ligeværd, lave hierarkier, enkelhed, hensyn til natur og miljø, interesse for at udveksle med resten af verden mv. Denne fællesnordiske platform af værdier kan bl.a. tilskrives den ydre geografiske placering, det fælles klima og den fælles historie og kultur. Den betyder i sidste ende, at mennesker på tværs af de nordiske lande, Grønland, Færøerne og Åland hurtigere kan nå hinanden og indgå i fællesskaber på kryds og tværs i den nordiske region. Det fælles værdigrundlag giver også befolkninger uden for Norden mulighed for lettere at identificere og placere de nordiske lande og områder på verdenskortet.

De fælles grundværdier er knyttet sammen med og afspejlet i vores nordiske kulturer, og det tværgående tema om værdier vil under det danske formandskab i 2015 være omdrejningspunktet for det vigtige samarbejde om kultur i nordisk regi.

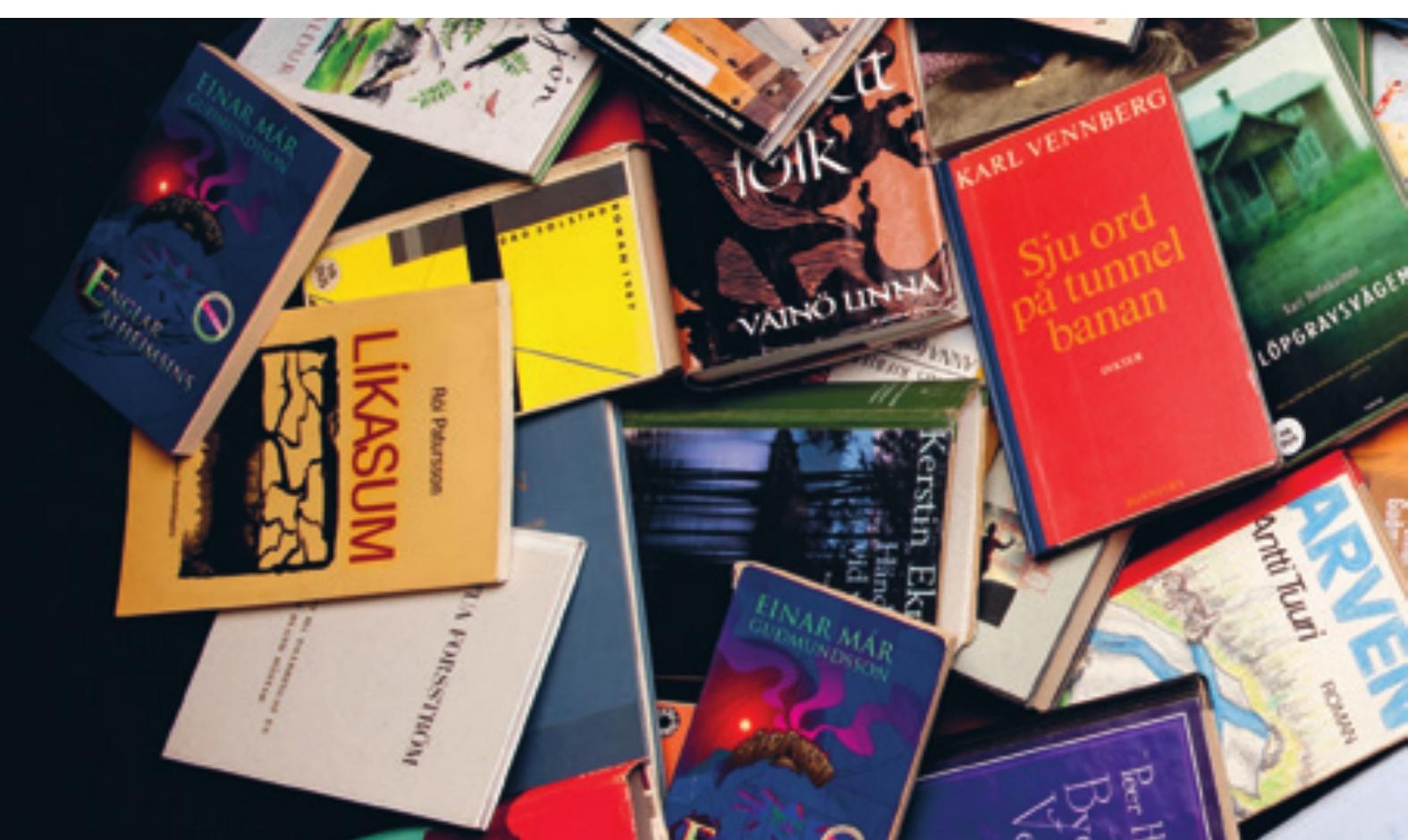


Værdier er bedst demonstreret i praksis, og vores værdier bliver ikke mindst tydeliggjort i den måde, vi arbejder og samarbejder på i Norden. Den fællesnordiske kultursatsning Nordic Cool i Washington i 2013 er et illustrativt eksempel på en vellykket profilering af nordisk kultur og Norden som helhed. Vi ønsker at bygge videre på de indhøstede erfaringer fra Nordic Cool-projektet og lægge op til et samarbejde om at skabe et "Nordic Cool"-koncept til fremtidige kultursatsninger. Udviklingen af et fælles koncept for profilering af Norden gennem fælles kulturudvekslingsinitiativer er et tværgående flagskibsprojekt for det danske formandskab, og "Nordic Cool"-konceptet skal i et bredere perspektiv ses som et bæredygtigt bidrag til visionen om et synligt Norden.

Det danske formandskab ønsker derudover at videreføre det nordiske kultursamarbejde med afsæt i de nordiske kulturministres strategi for 2013-2020 og de temaer, der er udpeget i strategien som aktuelle og påtrængende for de nordiske lande.

I 2015 vil formandskabet særligt følge op på temaerne om Det kreative Norden, Det unge Norden, Det bæredygtige Norden og Det digitale Norden gennem de formelle ministermøder og konferencer, ekspertmøder mv. Vi vil i den forbindelse sætte fokus på hele Norden ved at afholde formandskabsmøder i hele Rigsfællesskabet.

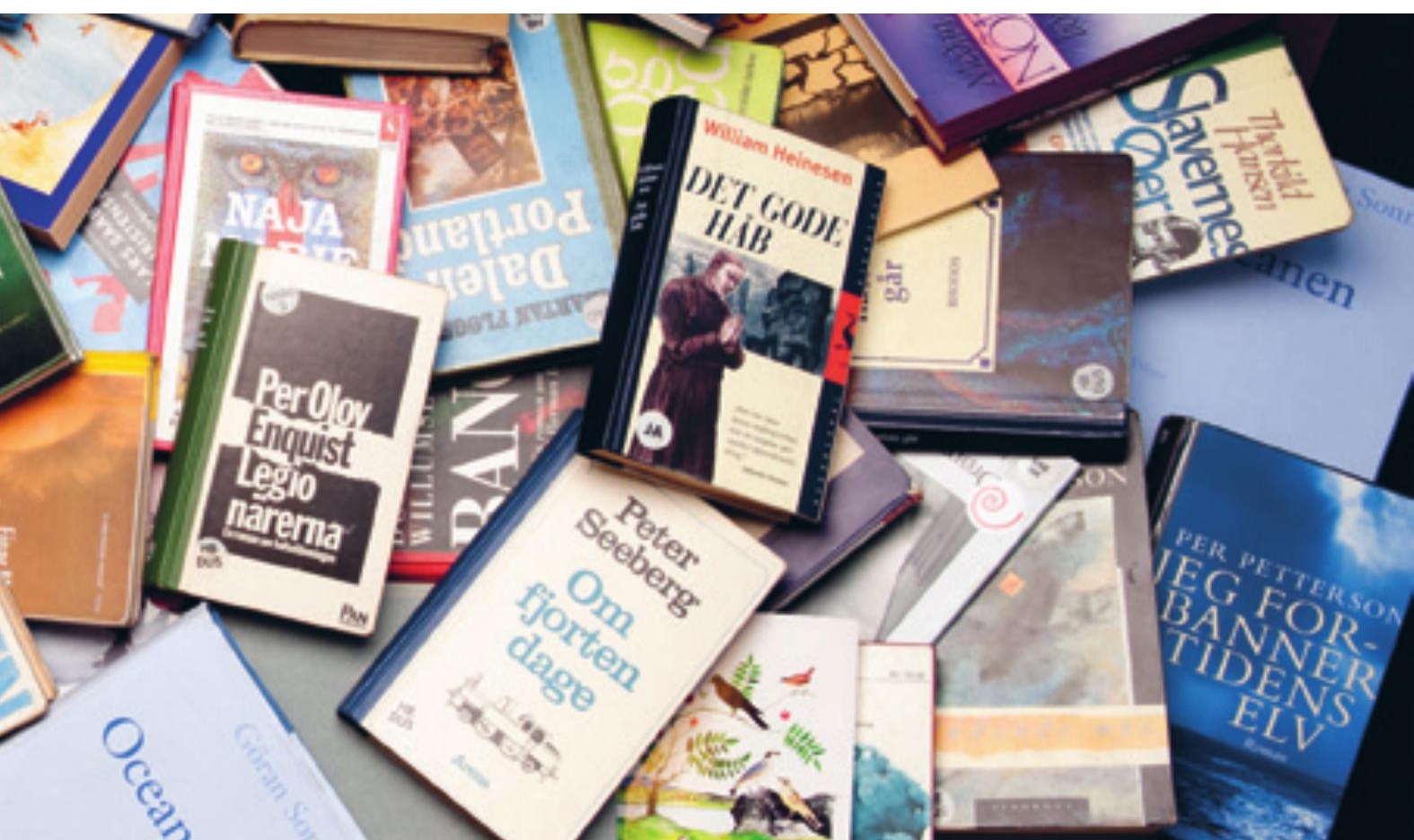




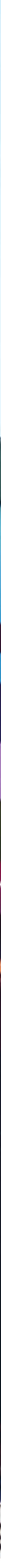




\section{Det kreative Norden}

\section{Udvikling af "Nordic Cool"-koncept til profilering af Norden}

Norden nyder positiv international opmærksomhed, når det gælder en lang række områder og emner - lige fra den nordiske samfundsmodel til ny nordisk mad og til nordic noir-litteratur og -film. Samtidig kan vi i Norden også drage stor fordel af at udveksle med lande uden for den nordiske region og på den måde sammen fremme gensidig inspiration med resten af verden.

Især i de senere år er mærkatet "Nordic" blevet knyttet stadigt tættere sammen med noget positivt og kvalitativt, og dette har bidraget til at styrke interessen for de nordiske lande på verdensplan. Endvidere forbindes "Nordic" med en åbenhed og nysgerrighed, der er et godt udgangspunkt for kulturudveksling.

Derfor satsede de nordiske lande stort, da de besluttede sig for at gå sammen om at gennemføre den fælles kultursatsning Nordic Cool i Washington i 2013. Satsningen betragtes af alle som en succes, og den store interesse for Nordic Cool har understreget den store internationale interesse, som nordisk kunst og kultur har i disse år.

De erfaringer, der blev høstet i forbindelse med gennemførelse af satsningen, har i sig selv været værdifulde. En af de vigtigste erfaringer var netop, at successen var nært knyttet til modtagere og afsenderes meget høje kvalitative krav til satsningens kunstneriske og kulturelle indhold. Projektet bidrog til at betræde helt nye stier, når det gælder større fællesnordiske kultursatsninger. Erfaringerne fra Nordic Coolinitiativet i Washington lader sig ikke direkte overføre til andre steder, men det er formandskabets hensigt, at de nordiske lande i fællesskab udvikler et holdbart koncept, der kan afpasses fremtidige destinationer for nordiske kulturudvekslingsinitiativer.

Flagskibsprojektet følger op på Nordisk Ministerråds nye strategi for profilering af Norden og målsætningen om at fremme en fælles platform for fortællinger om Norden gennem fællesnordiske aktiviteter. Endvidere skal projektet ses som et bidrag til de nordiske samarbejdsministres visioner om et synligt Norden.

Formandskabet ønsker at iværksætte et nordisk samarbejdsprojekt vedr. "Nordic Cool", der løber i 2015-17 og falder i to dele:

For det første en konceptudviklingsdel, der lægger op til at samle erfaringerne fra Nordic Cool-projektet fra 2013, således at der dels bliver udviklet et solidt organisatorisk set-up, så beslutningsstrukturer 
og samarbejdsparter ikke skal genopfindes, hver gang der opstår mulighed for en fælles kultursatsning, dels bliver samlet gode praktiske råd samt rettesnore for, hvornår det giver mening at præsentere en samlet fortælling om Norden frem for at optræde som individuelle lande.

For det andet en konkret del, der lægger op til i 2017 at gennemføre det udviklede "Nordic Cool"-koncept i praksis ved at iværksætte et fælles kulturfremstød a la "Nordic Cool".

Samarbejdet om konceptudviklingen vil blive forankret i en arbejdsgruppe med repræsentanter for alle de nordiske lande. De nærmere detaljer omkring gennemførelsen af den konkrete satsning vil blive fastlagt i arbejdsgruppen og forelagt kulturministrene, og det er tanken, at der som led i projektet vil blive afholdt en konference i løbet af foråret 2015. 


\section{Det unge Norden}

\section{Fokus på børns og unges kulturdeltagelse}

De nordiske lande er enige om, at børn og unge skal have en central plads i det fællesnordiske kultursamarbejde. Det nordiske kultursamarbejde har derfor som strategisk målsætning at prioritere børne- og ungekultur med henblik på at styrke børns og unges deltagelse i kulturlivet såvel som $\mathrm{i}$ samfundslivet generelt.

Til grund for samarbejdet i Norden om de yngste borgeres deltagelse i kultur ligger en respekt for børn og unge som selvstændige individer med rettigheder og krav om indflydelse over deres eget liv.

Børn og unge er de mest kreative og nyskabende medlemmer af vore samfund, og de er blandt de første til at opfange nye strømninger. Samtidig skal de lære deres kunstneriske og kulturelle arv at kende. Vi skal derfor løbende have fokus på børns og unges deltagelse i kulturlivet - hvad enten de forbruger eller selv skaber kunst og kultur.

Et væsentligt aspekt er børns og unges møde med arkitektur og deres deltagelse i udformningen af de fysiske rammer for deres liv. Arkitekturen er en så naturlig del af børns og unges hverdag, at de ofte ikke tænker over den fremtoning og indvirkning, en bygning eller et byrum har. Arkitekturen er et spejl på, hvordan vi lever, og de værdier og forestillinger, vi har om det gode liv, og hvordan vi ønsker, at samfundet skal udformes. Arkitekturen er derfor interessant i forhold til børn og unge, idet de fysiske rammer kan bidrage til børns og unges kulturelle, historiske og demokratiske dannelse.

Formandskabet vil bygge videre på den erfaringsudveksling, der har fundet sted som led i det nordiske kultursamarbejde, og sætte nordisk fokus på muligheder og udfordringer for fremme af borgernes, herunder børns og unges, møde med arkitekturen på tværs af de nordiske lande. Der vil blive afholdt en konference over temaet "Mødet med arkitekturen - børn, unge og voksne”. Konferencen supplerer det brede tværfaglige formandskabsprojekt Nordic Built Cities 2.0 under Ministerrådet for Erhvervs-, Energi- og Regionalpolitik, der har fokus på innovative løsninger til skabelse af smarte bæredygtige byområder.

Konferencen om børns, unges og voksnes møde med arkitekturen i Norden vil blive afholdt d. 27. marts 2015 i København. 


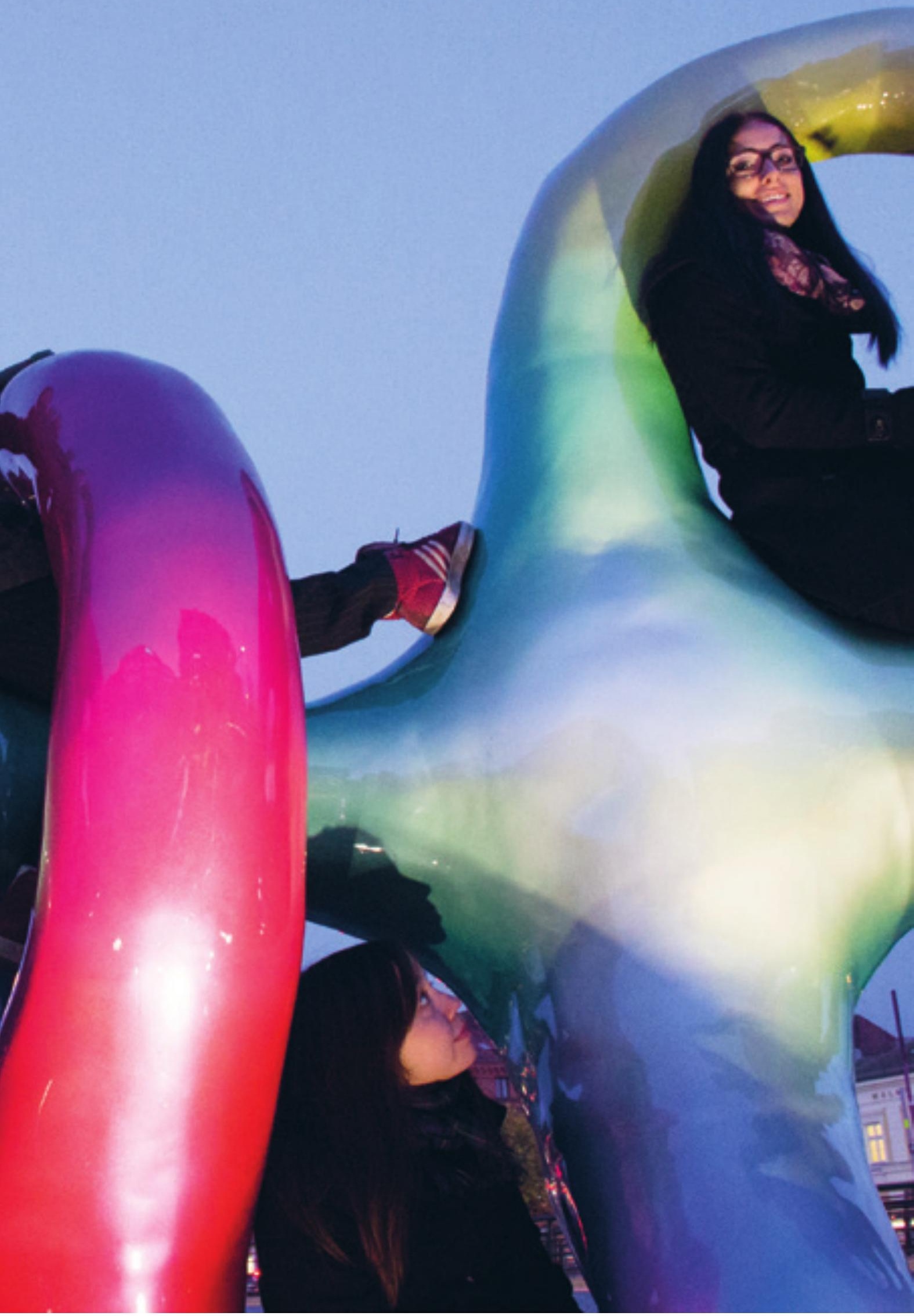


Formandskabet ønsker at bidrage til det nordiske samarbejde om børns og unges deltagelse i kulturlivet gennem en række yderligere konkrete initiativer. Sigtet er dels at have fokus på unges skabelse og samskabelse inden for kunst og kultur, dels at bidrage til den vigtige gensidige inspiration i Norden på børnekulturområdet.

For det første inviteres unge fra Norden til at deltage i et kunstnerisk "maker-event". Maker-eventet tager udgangspunkt i det verdensomspændende FabLab-netværk, som samler en række lokale FabLab'er rundt i verden, der stiller udstyr til rådighed for udvikling af nye idéer og danner rammer for digital samskabelse. Copenhagen FabLab under Københavns Kommunes Kultur- og Fritidsforvaltning står for eventet, som skal danne rammen om digital samskabelse af kunst, kultur og design med brug af ny teknologi som f.eks. en 3D-printer og laserskærere. "Maker-eventet" skal også være med til at synliggøre den kunstneriske del af "maker-kulturen" for øvrige unge - ved bl.a. at vise de unges værker og events i byrum i København.

Endvidere vil formandskabet sætte fokus på nordisk erfarings- og videnudveksling om strategier på børnekulturområdet. Efterhånden som børnekulturområdet er vokset, er behovet for at erfaringsudveksle og inspirere hinanden på nordisk plan steget. Formandskabet vil på den baggrund gennemføre et udvidet netværksmøde over temaet "nordiske strategier på børnekulturområdet", som finder sted i tilknytning til det årlige møde for det nordiske netværk om kunst, kultur og skole, der samler repræsentanter for kulturministerier og undervisningsministerier i Norden.

Formandskabet ønsker derudover at gå ud over den nordiske velfærdsmodels fintmaskede net og sætte fokus på muligheden for at give udsatte unge en stemme gennem kunst og kultur.

Der iværksættes et tværfagligt skriveprojekt med titlen "Ordskælv", der i første omgang retter sig mod en gruppe af udsatte unge fra Norden, som hver især får mulighed for at skrive en novelle, der handler om deres liv. De unge vil under forløbet få rådgivning og coaching fra frivillige og professionelle forfattere. Projektet vil munde ud $\mathrm{i}$ en novellesamling, der videreformidler de unges æstetiske vidnesbyrd og budskaber om deres livssituation. Novellesamlingen vil herefter kunne blive gjort tilgængelig for nordiske unge, som herigennem får mulighed for at læse om udfordringer, som jævnaldrende unge står over for. Derudover vil novellerne kunne læses af nordiske organisationer og myndigheder, kommuner og skoler, der ønsker at sætte fokus på udsatte unge. 
Projektet er et samarbejdsprojekt mellem den nordiske embedsmandskomité for kultur (EK-K) og den nordiske børne- og ungekomité (NORDBUK), hvis handlingsplan for 2014-2017 har fokus på at fremme et tværsektorielt samarbejde om børn og unge, ligesom projektet involverer flere ministerier. Formandskabssatsningen vil derfor også have som effekt, at der skabes synergi mellem kulturområdet og andre politikområder.

Projektet vil strække sig over hele 2015.

Ud over de ovenstående aktiviteter forventer formandskabet at iværksætte yderligere aktiviteter, som formidler nordisk kultur og sprog til børn og unge.

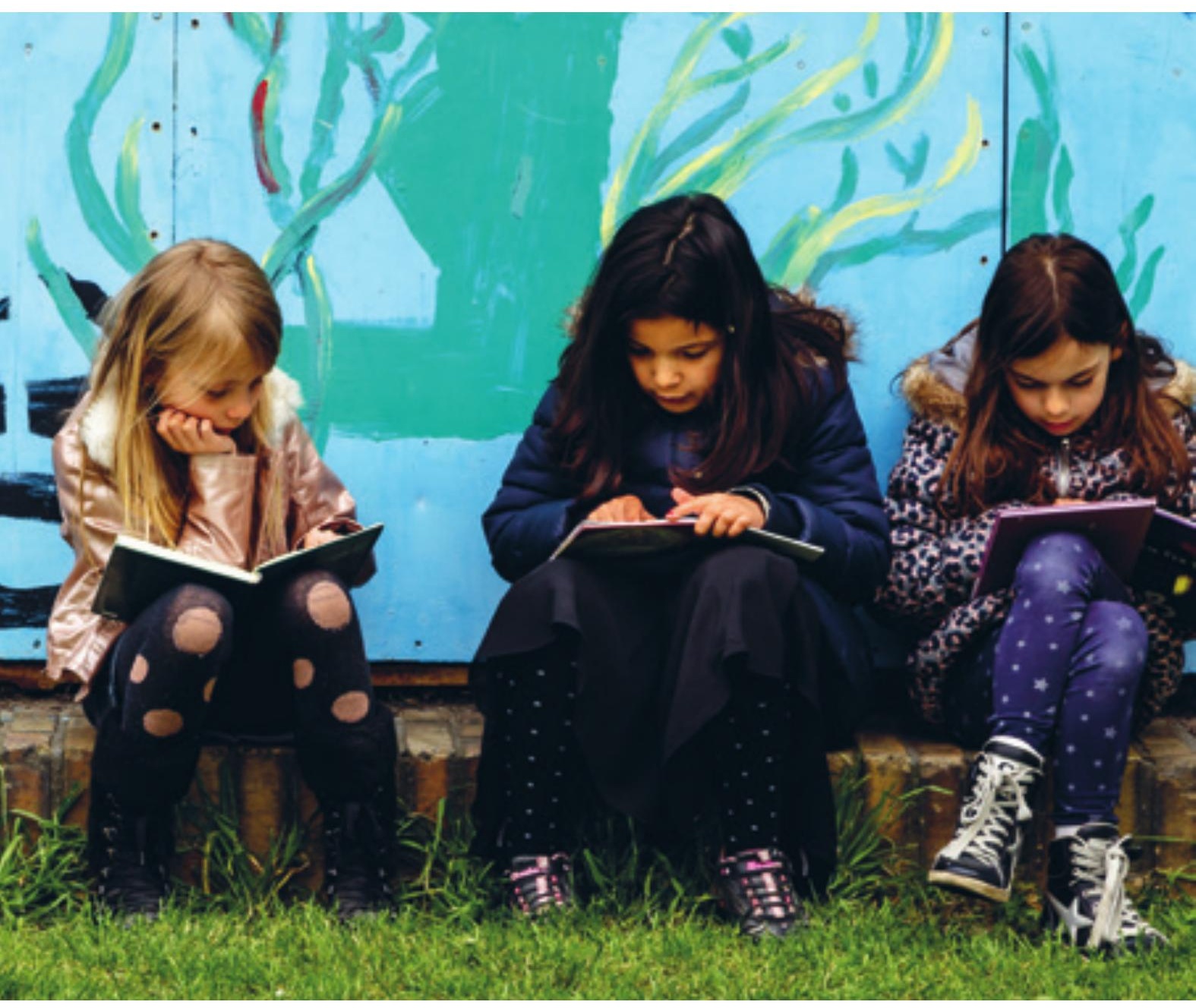




\section{Det bæredygtige Norden}

\section{Kulturens bidrag til bæredygtighed og aktuelle samfundsudfordringer}

Kultur er en vigtig grundpille for bæredygtig udvikling, først og fremmest fordi kulturelle aktiviteter bringer folk sammen, opfordrer til refleksion og er med til at skabe dialog om forholdet til natur og miljø og den vej, som udviklingen af vore samfund bør gå. Gennem en årrække har der i stigende omfang været røster, der argumenterer for, at ægte bæredygtighed også omfatter en kulturel dimension. Populært kan man sige, at det klassiske bæredygtighedsbegreb omhandler betingelserne for, at vi kan overleve. Forvalter vi ikke Jordens ressourcer omhyggeligt og bevidst, så er der ingen fælles fremtid. Tiden synes imidlertid moden til også at føje et kvalitativt element til begrebet bæredygtighed: kulturen. Dermed markeres, at vi ikke kun vil overleve. Vi vil også leve. Og det medvirker et dynamisk, aktivt og inkluderende kunst- og kulturliv til, at vi kan.

Gennem kunsten og kulturen stilles der også spørgsmål og anvises nye måder at tænke og handle på - f.eks. ved skildringer af temaer som forurening, overforbrug, manglende respekt for natur og miljø, holdbarhed,
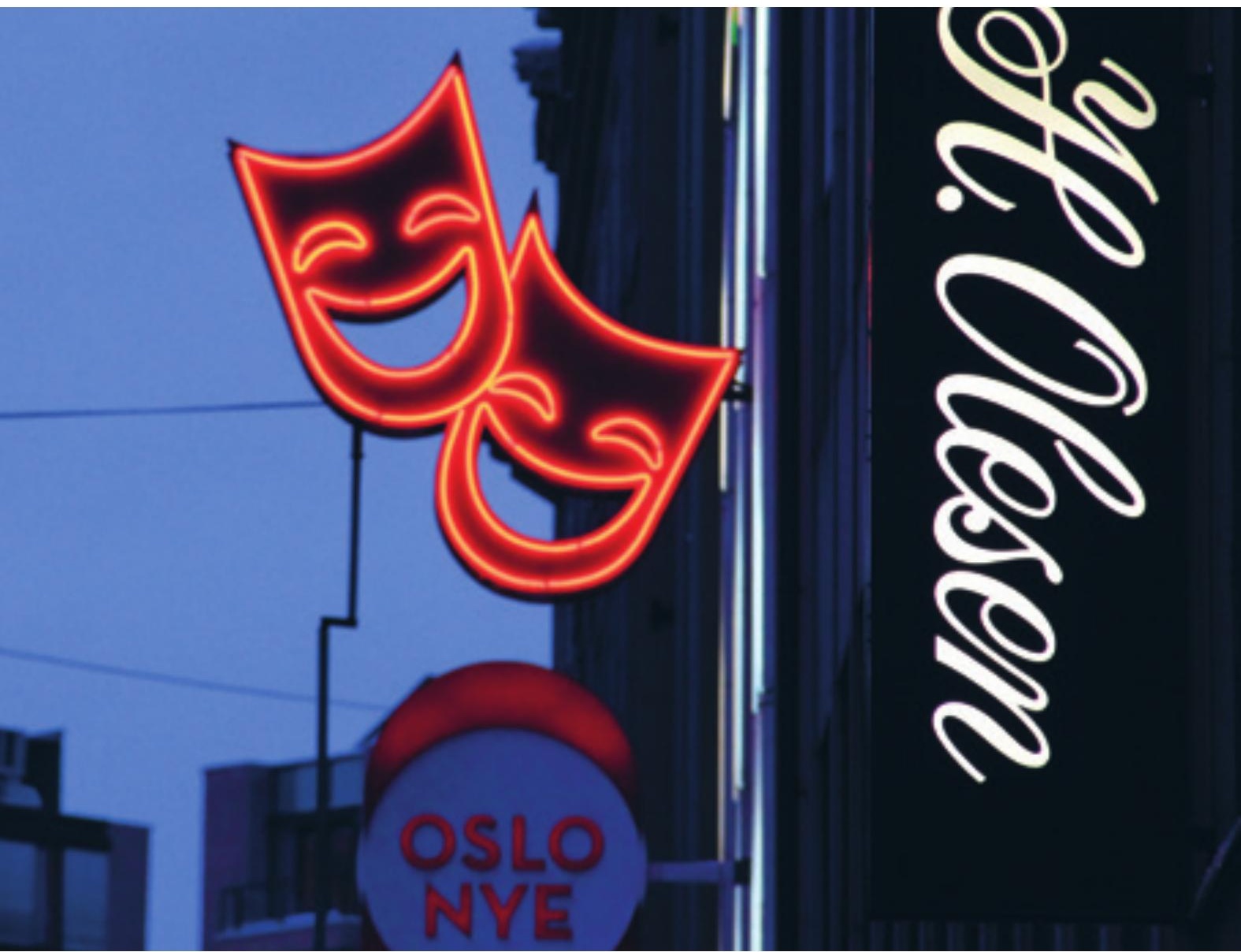
ressourcebevidsthed $\mathrm{mv}$. Set $\mathrm{i}$ et bredere perspektiv kan kulturelle aktiviteter anspore til kreative og innovative løsninger, som kan have positive afsmittende virkninger på økonomien, miljøet og samfundet som helhed.

Relevant for arbejdet med kultur og bæredygtighed er ikke kun at se på virkninger og konsekvenser, men også på processer henimod holdbare løsninger.

Formandskabet ønsker at sætte fokus på kultur som en grundlæggende del af bæredygtighedsbegrebet og kulturen som drivkraft for bæredygtig udvikling i bred forstand. Det vil være et væsentligt bidrag til at konkretisere kulturministrenes strategiske samarbejde om et bæredygtigt Norden.

Indsatsen vil blandt andet skele til initiativet "Culturability BSR", som er et bredt tværfagligt samarbejdsprojekt, der involverer samarbejdsfora og aktører i Norden, fra Østersøregionen og fra EU.

\section{Formandskabet ønsker at forfølge to målsætninger:}

1. At skabe rum for at dele viden erfaringer, strategier og visioner, som kan stimulere samarbejde på tværs af grænserne - det være sig i Norden, i Østersøregionen samt internationalt.

2. At udfolde og illustrere, hvordan kultur og bæredygtighed kan gå hånd $\mathrm{i}$ hånd og befordre hinanden som et svar på grænseoverskridende problemstillinger.

Formandskabet forventer at afholde en konference i november 2015. 



\section{Det digitale Norden}

\section{Udfordringer for public service i et nordisk perspektiv}

Der sker i disse år en hastig forandring af mediebilledet både i de nordiske lande og internationalt, og formandskabet ønsker at sætte fokus på udfordringer for public service i et nordisk perspektiv.

Både de traditionelle trykte medier og de traditionelle broadcastmedier tilbyder i stigende grad deres tjenester på nettet. Udviklingen i forbrugeradfærden går tilsvarende på faldende læsning af trykte aviser mv., faldende sening af traditionelt broadcast-tv og et stigende on demand-forbrug på nettet. Og udenlandske internetaktører som YouTube, Facebook, Google, Netflix mv. har i takt med udbredelsen af smart-tv's, smartphones og tablets positioneret sig som store aftagere af de nordiske borgeres medietid.

I den nye individualiserede og fragmenterede medievirkelighed er seningen og lytningen spredt på flere kanaler, og flere og flere vælger selv on demand, hvilken type programmer de vil se og høre.

De nordiske public service-medier har indtil nu haft en helt særlig rolle $\mathbf{i}$ forhold til at bidrage til den demokratiske debat i samfundet og til at give mulighed for fælles oplevelser med udgangspunkt i nordiske værdier.

Digitaliseringen af medieområdet stiller grundlæggende spørgsmål til public service-mediernes formål, rolle og virkemåde i de kommende år. Det er spørgsmål, som det danske formandskab ønsker at sætte på dagsordenen i Nordisk Ministerråd. Der er behov for at debattere og tage stilling til, hvordan public service-medierne kan eller skal tilgængeliggøre og fremme seningen af public service-indhold på de medieplatforme, befolkningen gør brug af.

Derfor ønsker det danske formandskab i forbindelse med kulturministerrådsmødet på Færøerne i foråret 2015 at lægge op til en temadiskussion for de nordiske kulturministre og repræsentanter for de nordiske public service-institutioner om udfordringer for public service i nordisk perspektiv.

Endvidere afs $ø$ ges muligheden for, at udviklingen inden for medieområdet kan være tema for Kulturforum 2015. 
Nordisk Ministerråd

Ved Stranden 18

DK-1061 København K

www.norden.org

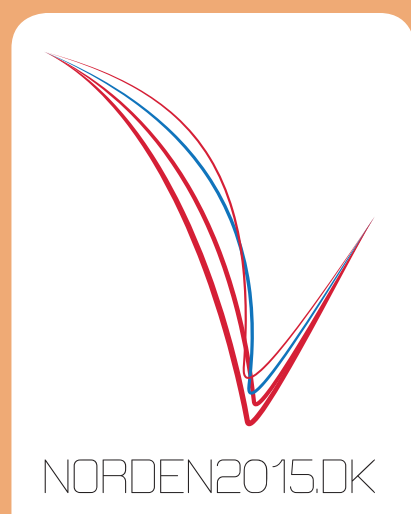

Yderligere information om Danmarks formandskab fås på www.norden2015.dk

Udenrigsministeriet Sekretariatet for Ministeren for Nordisk Samarbejde norden2015@um.dk

Asiatisk Plads 2

DK-1448 København K

\section{Danmark}

Telefon: +45 33920000

ANP 2015:702

ISBN 978-92-893-3911-7 (PRINT)

ISBN 978-92-893-3912-4 (PDF)

http://dx.doi.org/10.6027/ANP2015-702 